\title{
Virtual leadership? The echurch as a South African case in point
}

Author:
Ian Nell
Affiliation:
'Department of Practical
Theology and Missiology,
Stellenbosch University,
Cape Town, South Africa
Corresponding author:
lan Nell,
ianell@ sun.ac.za
Dates:
Received: 21 June 2016
Accepted: 17 Aug. 2016
Published: 16 Nov. 2016
How to cite this article:
Nell, I., 2016, 'Virtual
leadership? The echurch as a
South African case in point',
HTS Teologiese Studies/
Theological Studies $72(2)$,
a3570. http://dx.doi.
org/10.4102/hts.v72i2.3570
mobile device
to read online.
Copyright:
@ 2016 . The Authors.
Licensee: AOSIS. This work
is licensed under the
Creative Commons
Attribution License.

One of the most basic understandings of leadership relates to the fact that it is seen as the involvement of a person, group or organisation that influences and empowers enough people to follow and to bring about change in that area of life (Yukl 2010). A basic assumption in this understanding of leadership is that this kind of influencing and empowerment takes place in real-life situations and face-to-face contact between leaders and followers. The question that the article probes is, taking into account these basic assumptions about leadership, whether one can speak of 'virtual leadership' where there is not necessarily face-to-face contact between the leaders and the followers. I argue that it is indeed possible to speak of some kind of leadership and endeavour to investigate the so-called echurch as a case in point. An interview with the leader of the echurch in South Africa, Stephan Joubert, was published recently in the newspaper Die Kerkbode. It was this article that initiated the interest of the researcher to do some further exploration into this practical-theological phenomenon.

\section{Introduction}

Frits Gaum ${ }^{1}$ conducted an interview with the leader of the echurch, ${ }^{2}$ Dr Stephan Joubert, and the interview was published in Die Kerkbode (the official newspaper of the Dutch Reformed Church) on 3 December 2014. Gaum reports as follows:

\begin{abstract}
Joubert's other 'day job' is his involvement in the echurch. It started 12 years ago when he lived in New Zealand and initiated a ministry through email. It wasn't long before he had a list of more than a thousand people. A group of friends that supported his ministry and also wanted to help him to enlarge it convinced him to return to South Africa. The ministry was formalised and became known as the echurch, a non-profit organisation with a board exercising control. The echurch operates on different fronts. There is an electronic ministry making use of the webpage www.ekerk.org, where one can subscribe to the weekly newsletters. Another way in which the echurch is operative is by equipping leaders through a learning community, where they arrange day seminars, often inviting visitors from overseas who are considered as the pioneers on being church in the 21st century. Research is another leg of the work of the echurch. But the part of their work with which they are surprised by God's work is what they call the give-away ministry. They give away more of than $50 \%$ of their income from donations of individuals and businesses. For free, just like the grace of God is for free. They support orphanages and many projects helping poor people. ${ }^{3}$
\end{abstract}

Reading this interview on the life and work of Joubert generated some questions concerning my research interest in leadership studies: Can we speak about something such as virtual leadership? Is it in other words possible to exercise some form of leadership online and does it have an influence on the lives of people? If so, what might be the nature of this kind of leadership and in what ways can it be performed? These are the basic research questions that will be addressed in this article.

I address these questions in the following way: Firstly, I take a closer look at what is meant by leadership in the literature on the topic. Secondly, I focus on different aspects of the virtual world before discussing the echurch as a case study. This is done by reporting on empirical research conducted by means of qualitative methods consisting of a combination of document analysis and a semi-structured interview that I conducted with Joubert. Thirdly, I focus specifically on virtual leadership and discuss the different components of this form of leadership by making use of a theodramatic approach. In the final part, I present a critical discussion by making use of some recent literature on the topic of entrepreneurial leadership. 1.Frits Gaum is an emeritus Dutch Reformed minister who was formerly the editor of Die Kerkbode, the official newspaper of the Dutch
Reformed Church. Currently he still contributes to the newspaper through interviews with public and influential figures in the Reformed
tradition.

2.In Afrikaans it is called the 'ekerk', referring to the fact that it makes use of electronic media. The content of this reference is explored in more detail in the rest of the article by making a distinction between 'online church' and 'church online'.

3.This was translated by the author from the original Afrikaans. 


\section{Theoretical perspectives Leadership}

Reading through the literature on the topic of leadership, one finds the name of Gary Yukl (2010) as one of the leading scholars in the field. He wrote many books on the topic of leadership and developed a wide variety of theories in the field. In his book Leadership in Organizations (2010), his focus is mainly on leadership within professional organisations. Taking many different contexts into account, he developed the following definition of leadership:

Leadership is the process of influencing others to understand and agree about what needs to be done and how to do it, and the process of facilitating individual and collective efforts to accomplish shared objectives. (2010:26)

It is obvious that leadership is about 'influence' as well as the different ways of exercising this influence through individual and collective facilitation of shared goals.

The Dutch scholar Joke van Saane (2012:13-14) built on Yukl's definition and developed her own definition of leadership:

Leadership is the dynamic process where the leaders and followers influence one another, so that (1) agreement develops about the purpose and means of the group, (2) individual members and the group are optimally facilitated in an attempt to reach the goals of the group, and (3) the welfare of the group and the members are enhanced. ${ }^{4}$

Van Saane (2012:14) therefore distinguishes between three dimensions of leadership: (1) the person of the leader, (2) the individual followers, and (3) the group as a whole. According to her, these three are in continuous interaction with one another and in each situation create a unique dynamic that can at times be very complex. The specific context is of special importance and therefore, when it comes to religious leadership, we move to another level of complexity.

In concentrating on religious leadership, the insights of Michael Jinkins in his chapter 'Religious Leadership' in The Wiley-Blackwell Companion to Practical Theology (2012) point to the contested nature of leadership language within religious discourse: 'Though leadership has been an essential aspect of religious life from antiquity, its precise role and significance remain contested to this day in the academy and the church' (2012:308).

In his opinion, one of the main reasons lies in the very definition of the term and the fact that the ways, concepts and forms are utilised in many churches '[bear] the marks of secular ages, especially derived from business, social sciences, and political studies' (2012:309). When reflecting on the place and role of religious leadership in practical theology, Jinkins (2012:310) writes:

It remains an open question whether leadership as a field of study benefits from being understood as a discipline per se.

At present it appears more likely that leadership should be 4.This was translated by the author from the original Dutch. viewed as a subject matter, an area of specialization, or a field of study within practical theology, though its disparate core concerns may make it more difficult to describe its disciplinary subject definitively than other specializations (such as homiletics, liturgics and pastoral counselling). However conceived, religious leadership tends to focus on concerns such as leadership proper, organizational behaviour, management, stewardship, finance, conflict, power, change, and professional ethics.

From Jinkins's (2012) reflection on religious leadership, one gains an impression of the contested nature of the concept because of a number of factors that relate to aspects such as management, behaviour, conflict, power and change, which all belong to the leadership discourse. The contributions of Yukl, Van Saane and Jinkins led to the development of a number of concepts that can be used as heuristic devices when one starts to take a closer look at the way in which leadership is functioning in the echurch. Before a closer investigation is done of the descriptive-empirical aspects of the ministry of the echurch and the type of leadership operative in the organisation, it is important to ascertain a better picture of the so-called virtual world or the digital era. Some concepts of the virtual world and digital era are discussed and used together with insights on leadership to analyse the leadership of the echurch.

\section{The virtual world and the digital era}

Most people live in a virtual world and technology ${ }^{5}$ plays a central role in this so-called digital era. ${ }^{6}$ According to Cloete (2015:1), excellent research has been done in the fields of sociology and communication science, but the problem is that not enough theological reflection has been done on the way the digital world influences our lives. Therefore, it is important to try to gain a better understanding of what is known as the virtual or digital world or the digital era. ${ }^{7}$ Trying to figure out what role leadership can play in this world is also part of this endeavour. Nancy Baym (2010:1) makes the following remark in her book Personal Connections in the Digital Age when she writes:

There have never been more ways to communicate with one another than there are right now. Once limited to face to face conversation, over the last several millennia we have steadily develop new technologies for interaction. The digital age is distinguished by rapid transformations in the kinds of technological mediation through which we encounter one another.

5.For a discussion of the role of technology in our lives, see also the contribution of Graham (2009:222-227), who is of the opinion that technology operates according
to its own set of values that relates to the unique nature of what it means to be to its own set of values that relates to the unique nature of what it means to be
human. Therefore, according to Graham, technology is not a luxury anymore and human. Therefore, according to Graham, technology is not a luxury anymore and
not only forms part of our daily survival, but is also the vehicle of transformation that is changing the world around us and directly impacts the way we are thinking about ourselves.

6.According to Schön et al. (1999) the danger exists that poor communities can be excluded from the advantages of the digital world; they are however also of the opinion that the isolation of the poor can be ended by developing new approaches to social inequality through the cyberworld. Their book is full of examples of how it can be done.

7.Cloete $(2015: 1)$ describes the characteristics of the digital age 'as "networked" via different forms of media like telephones and the Internet. Digital media are also interactive in terms of its responsiveness between the user and media object. The interactive in terms of its responsiveness between the user and media object. The
different media forms are composed of nodes and blocks which are connected by different links between them, which make the text hypertextual'. 
Miller (2011:12-22) helps us to understand something more about the digital era in his discussion of certain key elements of the digital media and the way they relate to the network society, the interactivity of communication, the hypertextual nature of the Internet and the important role that big data play. According to Miller (2011:12), the three basic elements of the digital era can be described as 'technical processes (the technological building blocks), cultural forms (the way in which digital media objects are created, encountered and used) and immersive experience (the environments that digital media create)'.

To live in the digital era is not without its problems. Cloete (2015:2), concurring with the thoughts of Miller, asks serious questions, inter alia: "How can we be absent yet also present?" and "What is the self if it is not in a body?" In other words: "Where and how is the real self in digital communication?"' Baym (2010:3) also asks penetrating questions in this regard, for example about the difference between the online and the offline self and whether they might not be in contradiction to each other. According to Baym (2010:4), it can even happen that the borders between a human being and a machine can collapse, with the result that the body and the self can be thrown into a situation of flux. This again can lead to a situation where the borders between personal and mass communication can fade even to the point that it becomes disruptive for both. Therefore, the question that belongs to the heart of these fluid borders is: 'What is real and what is considered virtual?' Baym (2010:5) describes the challenge this situation poses in the following way: 'Digital media calls into question the very authenticity of our identities and relationships and practice' (2010:5).

The question of Baym leads one to the question about the unique nature of what can be called virtual leadership. Kerfoot (2010:117) uses the insights of different scholars and writes that leadership entails exercising leadership in a community that differs from the physical environment in that they communicate and interact, even coordinate people, through electronic media. According to her, successful virtual leaders learn how to cross the boundaries of time, space and culture in exercising their leadership roles. Therefore, skills and capacities that virtual leaders need include aspects such as the following:

- Listening to see - there are no physical spaces where one can observe people's behaviour, thus one has to use one's imagination and concentrate to listen with attention (2010:118).

- Creating aliveness - which entails creating a 'community of practice' with a feeling of aliveness. 'Virtual leaders must use evolving social media technology to create a virtual sense of aliveness and a high-performing virtual community within the organization' (2010:118).

- Communicating effectively - from the previous it is obvious that the virtual leader is dependent on diverse forms of technology (email, webpages, blogs, etc.), which also means that it is necessary to do sound preparation before starting to communicate (2010:118).
She concludes with the words:

The evolution into virtual leadership is one of the requirements for evolving a career in leadership. Fortunately there is more information available as this discipline evolves. As technology is developed and utilized, virtual leaders will have many ways to 'listen to see'. (2010:119)

Caulat (2006:6) identifies in her research a number of factors that are expected of a virtual leader:

Building and nurturing relationships where social aspects are essential, maintaining presence in spite of being remote, generating information as an act of co-creation rather than a content, co-creating shared realities, allowing for planning and emergence, monitoring what people achieve rather than what they do, bringing the informal into the formal, redefining the 'etiquette' for their own specific team, project managing, managing conflict, working with diversity, establishing the context, managing workload in relation to time available and time zones, managing own and others' stress.

Indeed a long list ... With a bit more insight into what is understood when one uses the concept of virtual leadership, it is now time to take a closer look at the echurch as a case in point.

\section{A description of the echurch}

A descriptive-empirical approach in describing some aspects of the echurch was undertaken by making use of two main sources. The first was a semi-structured interview ${ }^{8}$ that I conducted with the leader of the echurch and the second was a document analysis of the information on the website of the echurch (http://www.ekerk.org/). In the interview, I posed the following questions to Joubert, and what follows are excerpts from the transcriptions of the answers he gave.

Tell me something about the origins and history of the echurch and some of the people and interest groups involved.

From the interview it became clear that the echurch is now (2015) 13 years in existence. It started as a dream of Joubert in New Zealand after he left the University of Pretoria and thought about a digital ministry while abroad. Individuals bought into his dream and they started out with nothing. In his own words:

It was a kind of faith ministry with knowledgeable people from different backgrounds that came to offer their help. It started to grow and we established a board, a full-time woman to handle the website and some more people later. It was and still is an independent ministry that relies on donations.

Everybody working at the echurch who receives money also has other sources of income in order to serve in the kingdom and to keep costs lower than most other ministries, which often drown under the burden of salaries.

8.The interview took place on 30 April 2015 at 15:00 in Stellenbosch, during a visit of Dr Stephan Joubert to the Western Cape. 
Among the group that forms part of the team are people who act as managers; manage the finances; handle the echurch Bible school; coordinate projects and leadership tours; take responsibility for the webinars; organise leadership development, also known as 'learning communities', all over South Africa; and handle webpage design, creativity and the general 'look and feel' of the echurch. There are also people who are responsible for the technical 'hosting' of articles and material on the Afrikaans webpage, handling the English blogs and translating Afrikaans content into English.

\section{How do you understand the culture and context?}

The vision of the echurch is described by Joubert as: 'Jesus visible, touchable and understandable'. They focus on the following areas:

Spiritual growth via a website and digital newsletters. The echurch sends out newsletters with the titles 'Goeie Nuus' and 'Kernkrag' [Good News and Core Power] twice a week. Together the subscribers to the weekly newsletters and emails constitute just under 50000 individual email addresses. Two years ago they established a large research department producing a report every 6 weeks on the newest trends in the post-modern world that they think Christians should take note of, from bio-technology to 'selfies'. They also have regular live webinars where Bible schools and some of their trend reports are presented, which is a growing leg of the echurch.

Equipment of leadership, taking place at grassroots level through learning communities with leaders from many different churches. They invite visitors from abroad such as Alan Hirsch and Leonard Sweet. They also have a person availing his lodge in the Bushveld, where they conduct the development of their spiritual leaders. Over the past couple of years they have equipped more than a hundred ministers and pastors through these sessions. They also have two annual tours for leaders - one to Leonard Sweet and one to other innovating people in the USA, where they invite up to 20 ministers as well as people from the business world. They also have a 'blessing ministry' for spiritual leaders, where they annually sponsor two students studying theology at the University of Pretoria by paying them a small salary. They want to give these students the opportunity to enjoy their studies and to have enough time for study and thinking. Another interesting part of their ministry is the 'Day of sages'. In Joubert's own words:

Every year we organise a 'Day of sages' in the Atterbury Theatre in Pretoria. We invite wise leaders to come and share their insights with us. This year we invited Pik Botha, Brand Pretorius, Theuns Eloff and Naas Botha.

For the past 5 years, they also have a weekly conversation over a cup of coffee taking place every Friday at 09:00 in the Basiliah Restaurant at the Moreletapark Church. The echurch uses the facilities for an hour and approximately 120 to 150 people normally attend these occasions, which entail Bible teaching accompanied by drinking coffee. All the funds gathered during these sessions are deposited into the account of the diaconal ministries of the echurch.

Involvement in need. They are very involved in a number of need (diaconal) ministries. The echurch's board of six members expects to give away close to $50 \%$ of the income they annually receive. In Joubert's own words:

Currently echurch is involved with PEN action in the city centre of Pretoria, the Echo Youth movement, the Mosaic ministry in Potchefstroom, working amongst children with AIDS, therapy at Louis Botha orphanage, Morester orphanage in Rustenburg, Herfsland home for the elderly in the East Rand where we provide meals and other forms of life support to 40 elderly people, 'Word for word' in Cape Town and a few other ministries on an ad hoc base in the Western Cape.

\section{How do you understand the audience that you want to serve?}

They focus on Afrikaans-speaking people and also a smaller English audience in terms of their vision. Church affiliation is not important to them. Joubert made the following statement about the echurch audience: 'We also realised that many of the members participating in echurch are somewhat disillusioned and unchurched, but most of them are not prepared to leave the church permanently or are extraordinarily angry at the church'. The vision of the echurch is a kingdom-orientated ministry that is not a substitute or surrogate ministry for their local congregations. They are not an 'online church', but part of the 'church online'.

In terms of the structure of the leadership, how do the leadership, processes and organisation of the echurch operate?

According to Joubert, they follow an organic model. Although he sees himself as the designated leader, he believes in organic leadership, where different people are supposed to take the lead at different times. He admits that he does not exactly know how everything works in the echurch and describes it in the following way:

Person A for example is responsible for the finances. We do have a board because we are an Article 21 organisation and two of our board members are supporting Person A with the finances. We have a 120-seconds rule when it comes to the distribution of funds and I am also involved in that. If we are not sure after 2 minutes what to do, we leave it for the next meeting. Our organisation is very strong on relationships.

\section{How do you see the echurch's impact and efficiency?}

Joubert is of the opinion that this is difficult to measure and mentioned some statistics already referred to. They send messages and newsletters weekly to approximately 50000 individual email addresses. Their webpages, blogs and Facebook page attract quite a number of visitors. Their leadership training via learning communities had more than 
800 attendees in 2015, mainly because of the presence of Leonard Sweet.

\section{Data analysis}

During the content analysis of the data, a number of interesting topics were identified that were related inter alia to the echurch context, technology and digital communication, different forms of ministry, spiritual growth and the equipment of leadership. Looking at these concepts one could say that the echurch is a dramatic new way of performing church in contemporary society. In concentrating on this performative aspect of being church, I therefore make use of 'theo-dramatic lenses' to take a closer look at the data. Working with this approach it was possible to identify at least four aspects that constitute the main components of the drama, namely the stage, the plot, the audience and the role of leadership.

Before a discussion of the different aspects it is important to give some clarification on what is understood as a theodramatic approach. ${ }^{9}$ A theo-dramatic paradigm is an approach where drama and the art of the theatre provide a paradigm for the task of reflecting on some faith practices, in this case the practice of virtual leadership. The use of drama as an image of God's activities is not new. ${ }^{10}$ Karl Barth, following in the footsteps of John Calvin, described the creation of the cosmos by God as the Theatrum Gloria Dei, in which the created reality was seen as the theatre for God's great deeds and also as part of his grace and salvation (Thompson 2006:5). In this paradigm, drama (a text-centred concept) and theatre (a performance-centred concept) become analogies through which one can understand history in its relationship to the author of this drama. In this regard, creation is indeed the theatre of God's glory and finds expression in the drama of Jesus, the main character that appears on the stage. With this in mind, the following aspects were investigated.

\section{The stage and the role of technology and digital communication}

Little doubt exists that the stage looks quite different in the case of virtual leadership than in an institutional context or within the context of normal congregational ministry. Van den Berg (2012:3) illustrates in his research that the postmodern person is not only surrounded by technology, but is also very dependent on it. At the same time we are not yet sure what the effect of all of this might be on people's lives. That the nature of technology and digital communication is contested stands

9.Theo-drama is a term that was developed by Hans Urs von Balthasar in a series of books published in the early 1980s. Theological-dramatic theory takes seriously the narrative or dramatic way that God reveals Godself. God is seen as acting first within the inner relationships of love inside the Trinity, but then also in relation to the world through acts of creation, redemption and glorification. Theo-drama also implies that we, God's creatures, are invited to find our own stories taken up into the larger story of the Trinity. According to Von Balthasar (1988), it is an approach that has the potential to combine a number of theological methods by making use of dramatic categories. Seen from this perspective, the world becomes the stage on which God's story is dramatically performed, with the faithful having the responsibility to act with integrity in a community of love and justice.

10.There is an interest in the potential of drama from a diversity of backgrounds, not only in practical theology, but also in most of the disciplines within theology. For only in practical theology, but also in wright (1992) and An history: Quash (2005); Tystematic theolor history: Quash (2005); systematic theology: Brown (2008), Vanhoozer (2005) and Von Balthasar (1988); and practical theology: Osmer (2005), Healy (2000), and Childers and Schmit (2008). without reasoning. As already referred to in the section on the virtual world and the digital era, more research is needed on different aspects concerning the stage of the echurch before one will be in the position to develop a more balanced perspective.

On the positive side concerning virtual leadership, it is quite apparent that there are a number of advantages when one starts to reflect on the role of technology and digital communication. In this regard one can think of aspects such as 'connectivity', which not only refers to speed, bandwidth or connection capability but especially to participants' need for interconnectivity in this new reality, as is evident from the data. In this regard one also finds language in which concepts such as 'links, social networks, followers, friends' are used (Joubert 2010:52). This kind of language in the digital world makes it possible to participate in international meetings, group discussions and even $\mathrm{PhD}$ thesis defences with people from different continents. According to Rice (2009) and Friesen (2009), it also relates to people's intense search to escape from their enclaves of loneliness and is deeply about the core of psychological well-being that one finds in healing relationships. Facebook is a good example of this through the possibility of connections with different friends, creating for many a feeling of 'home'. It is indeed a place where one can keep everything together that one deems important, such as photos and a life narrative. It is also a place where people find and inform their families and exercise some sort of control over their environment and just be themselves. One finds these thoughts in Joubert's reflection on the audience the echurch wants to serve, as quoted in Section 3.

Dawson (2004:6) makes an important distinction in this regard between 'religion online' and 'online religion'. He describes the difference in the following way: 'Religion online ... invites internet visitors to participate in religious activities' that can be understood as a variety of activities, such as prayers, Bible studies, counselling and even church services. On the other hand, '[o]nline religion ... is the provision of information about and/or services related to various religious groups and traditions'. In reality many different forms of religion on the Internet fit somewhere inbetween these two categories where both information and participation are offered. In this regard it is interesting to hear that Joubert is of the opinion that the echurch is not an 'online church' but a 'church online'.

However, these insights should not blind us to a number of dark spots that one finds on the stage of virtual leadership. The instruments or tools that we use are not neutral and Hipps (2009:45) writes in this regard: 'The tools we use to think actually shape the way we think. The same applies to our faith as well'. The virtual world undoubtedly places great emphasis on the role of the visual and Hipps (2009:76-77) indeed points to the fact that images play on our feelings rather than stimulate our thoughts. Images do not invite one to arguments but stimulate experience. These ideas have important consequences for the practices of Bible reading and interpretation within digital realities. A situation that is 
closely related to the previous concerns the absence of specialists who can encourage critical thinking. Leadbeater (2009:32 ff.) is of the opinion that it can easily end up in manipulation, where a reality is created where all views, opinions and ideas are on the same level; therefore, a re-evaluation of specialists and scholars within cyberspace is of utmost necessity. A last blind spot on the stage concerns the accusation that one often comes across about the superficiality of the different forms of connection that one finds within the virtual world. Hipps (2009:107) describes how 'the near become far, and the far are brought near', whereas Siegel (2008:6) even goes as far as calling cyberspace 'the first social environment to serve the needs of the isolated, elevated, asocial individual', meaning that relationships, emotions and experiences can be managed and controlled at a safe distance. According to Joubert (2010:55), these aspects can quickly make individuals dull to real caring and for selfless servitude towards other people struggling with personal sufferings and sacrifices.

A last comment about the virtual stage relates to what Joubert (2010:58) calls 'the philosophy around ministry in the digital era'. According to him, the typical question that emanates from print culture is: Can it be that the use of digital media is a stumbling block in the way of the message? This question is stated differently in the digital world that entails narratives and an 'image-driven culture'. The question is rather: Which forms of communication are we convinced are worthy to communicate the message of the gospel? In this regard the informative work of Wilson and Moore (2008) shows how digital media can be understood in four different ways within faith communities, namely:

'Media as the arts' through artistic beauty and different aesthetical forms also in the history of the church, 'media as information' where the media can act as a medium for transformation in the image of Christ, 'media as mission and evangelisation' where digital media endeavours to invite people into the family of faith, and 'media as cultural language' where the purpose is the transformation of culture through the mediation of the presence of the church in the world.

If one takes a closer look at the data through these lenses, it looks as though the echurch is making use of all four forms of the digital media in service of the church and the kingdom. More explanation follows later.

\section{The plot consisting of different forms of ministry}

In the analysis of the data, both from the interview with Joubert and from the information on their website, it becomes clear how they structure the plot of the ministries of the echurch by making use of three basic activities, namely spiritual growth, equipment of leadership and involvement in need. Spiritual growth relates to the digital newsletters that are distributed through the webpage and in different formats. The content of the newsletters is normally reflections on passages from scripture in conversation with everyday experiences. For example, the theme of Joubert's most recent article (2016) is 'God is altyd tuis' [God is always home], which is actually part of a quote from Meister Eckhardt: 'God is at home, it's we who have gone out for a walk'. In this article he reflects on the different ways many people blame God for what is happening in their lives, without any thoughts on personal responsibility. Spiritual growth is also effected through the work of the research department, webinars, Bible schools and trend reports, as discussed earlier in this article.

The processes of equipment of leadership is facilitated by the learning communities with different leaders from different denominations, the face-to-face opportunities presented across the country, presentations by visitors from abroad, the annual tours for groups of leaders to the USA, Bible school tours to Israel, the so-called blessing ministry for spiritual leaders, the support to students studying theology and the Day of sages.

The last component of the plot of the echurch is involvement in need, known as the need (diaconal) ministry. This refers to the $50 \%$ of the annual income donated to projects helping people in need.

From the above description it is clear that the plot of the ministry in the echurch consists of a combination of virtual and face-to-face spaces and places. Although Joubert belongs to the Dutch Reformed Church, he steers away from confessional choices for the plot of the echurch, and the choice for specific ministries by the board of six members focuses on faith nurturing of individuals, development of leadership capacities and the different forms of need in the world.

\section{The audience, their participation and the challenges of community}

With the focus on the audience and their participation in koinonia (community), we again face one of the most teasing questions concerning faith and cyberspace: What entails participation and community in cyberspace?

In the reflection on the audience or the 'community' under discussion here, little consensus exists on the precise meaning of the concept (Campbell 2013:59; Miller 2011:184). According to Baym (2010:74), it remains a useful concept relating to interactions among and social relations between people. I already referred to the crucial role of connectivity in the digital culture because it consists of different forms of communication among people. However, not all are convinced that community in a digital culture is really still community. According to Miller (2011:97), the original understanding of community is being replaced by different networks to which people belong according to their different interests. It is also clear from the data that people 'choose' to belong to the echurch's network. Byam (2010:9) speaks about 'networked individualism' that one finds in these kind of communities, meaning that participants create their own communities, causing a shift in the nature of community.

In this regard it is also interesting to find in the data that the focus of the echurch is on an Afrikaans audience 
for whom church affiliation is not important and who is even 'unchurched and disillusioned'. There is certainly a disappointment with the institutional church, but not a total unfamiliarity, while at the same time there is a pursuit of 'being church' in the virtual world.

Estes (2009) summarised this development in the following way: '[A] virtual world is a created space where people can interact as if in the real world, but through some kind of technological medium'. In this regard it is important to understand that the virtual world as virtual world is not a fictional world and is therefore not only a possibility but also a mode of reality.

Campbell (2013:63) points to the fact that research confirms that a greater integration of online and offline communities is taking place in spite of the fact that online communities are often not seen as authentic and realistic. He concludes that one should rather see offline and online communities as complementary, where the one acts as an extension of the other without the one excluding the other. It looks to me as though this description can be successfully applied to the circumstances of the echurch. The fact that Joubert himself refers to the echurch as 'church online' implies that they want to give the members the opportunity to participate in Christian practices by making use of electronic means, as also became clear in the description of the plot.

\section{The role of leadership and the rise of the so-called entrepreneurial pastor}

In answer to the question on the structure of the leadership of the church and the processes and organisation, Joubert gave an explanation of the organic model of the church. One sees here the different roles and responsibilities of the people serving on the board.

What is clear at first glance is that one finds another kind of leadership in this situation than is associated with the traditional offices normally found in main-line churches. Joubert refers to himself as the designated leader, but it is clear that his style of leadership and the initiative he took because of the vision he received function in a different way than is the case in the average Dutch Reformed Church, of which he is a member.

In a recent contribution by De Wet (2015:129-141), he discusses what he calls the 'rise of the entrepreneurial pastor'. When one studies the origin and development of leadership in the echurch, entrepreneurialism and its relationship to leadership help one to make sense and find words for what is happening in the echurch. According to De Wet (2015:130-133), four different factors can be identified that gave impetus to the development of this kind of leadership in South Africa, which can be applied to the situation of the echurch.

Firstly, there is what he calls 'the force of globalization' (2015:130), where churches are challenged by dramatic changes in the socio-political context. These processes also call for a more holistic approach to the identity and ministry of the church. Secondly, one finds what he calls 'the entrepreneurialisation of the pastorate' (2015:131), which directly links to the rise of the information era and the important role that technology started to play. The mega churches in some of South Africa's suburbs are examples of this development. Thirdly, there is 'the tide of materialism and its responsive proliferation of managerialism and business education' (2015:131). Neoliberalism has not only been the basic philosophical choice of the government since 1994, it has also become part of many churches' ministerial philosophy. Many churches and congregations function like cooperative organisations that endeavour to be socially relevant and also economically viable. Last, he refers to 'the critical change in the cultural fabric of society' (2015:132), resulting in the change of many of the fundamental aspects of our reality. He writes, 'it is introducing new epistemologies, thereby changing the very nature, structure, and dynamic of knowledge; new spatialities - "space" and "place" is no longer a constant, and the defining characteristic of these new geographies is mobility' (2015:132). As part of this last factor he refers specifically to what he even calls 'e-architecture', indicating that churches do not need physical spaces to gather anymore and have also started to create semi- or fully online opportunities to meet for worship. He also refers in this case to Joubert's echurch.

Although Joubert refers to the echurch's model of leadership as organic leadership, it becomes clear from the thoughts of De Wet that the so-called entrepreneurial pastor plays an important role in this development and acts as a kind of precondition for the organic model. This brings us to the last section, where a number of evaluating comments on virtual leadership are made.

\section{Critical evaluation of virtual leadership}

In approaching the task of a critical evaluation of the echurch as a form of virtual leadership, I make use of the three categories or streams that De Wet (2015:133-136) distinguishes when he discusses the topic under the heading 'The development of a theology of entrepreneurial pastoralism'. He distinguishes between the following three streams that had an influence in South Africa and that were heavily influenced by the North American context:

Classical entrepreneurial pastoralism (De Wet 2015:134) is the first stream and is characterised by the work and ministry of people such as John Maxwell, Robert Schuller and Rick Warren, who all popularised leadership and leadership development in ecclesiastical circles in the USA. Leadership models are often seen by them as universally applicable in different contexts.

Prosperity theology and televangelism (De Wet 2015:134) is the second stream in which one finds the names of people 
such as T.D. Jakes, Joyce Meyer and Joel Osteen. This is also a more Pentecostal-charismatic stream that is characterised by televangelism and the prosperity gospel. In this stream, leadership and especially financial management are important characteristics. The underlying theology of this stream is often very biblicist and fundamentalist.

Postmodern and neo-orthodox entrepreneurial pastoralism (De Wet 2015:135) is the last stream, characterised by the work of people such as Bill Hybels, Leonard Sweet, Brian McLaren and George Barna. According to De Wet (2015:135), this is a popular group 'who have formulated a postmodern and neoorthodox entrepreneurial pastoralism'. Two of the central concepts that one finds in the work and theology of this group are 'seeker-sensitive' and 'missional', with considerable attention paid to public theology. In particular, Hybels, Sweet and McLaren are quite influential in the South African context in that all of them have visited some of the megachurches in South Africa from time to time, with Sweet having done so a number of times. In the data we also saw references to Sweet's influence on the echurch. It is also interesting to see how many of the churches in South Africa took over their kind of theology and ministerial philosophy. Furthermore it is among this group that one finds the development of the so-called emergent church, with considerable emphasis on missionality, inclusivity and a participating spirituality.

In analysing the data by making use of the above distinctions of De Wet, it is very obvious that the echurch of Joubert can be seen as belonging to the third stream. As mentioned, Joubert himself refers to the important role that the representatives of the third stream play in their ministry and theology, with specific reference to the role of Leonard Sweet. Not only do they invite him annually to South Africa, but Joubert also takes a group of South African church leaders to the USA on a regular basis to get to know Sweet better in his own context.

The way in which Joubert and his leadership team developed their vision for a digital ministry evolving into the shape of the echurch with a specific style of leadership leaves one with much respect and appreciation, knowing that it could not have been done without courage and endurance. In light of the fact that the vision of the echurch supports an organic form of leadership where participation and dialogue play an important role, I think it is important to formulate a number of points and questions for discussion concerning the form and meaning of being a virtual church and the kind of entrepreneurial leadership that one finds in their approach.

The first point relates to whether the choice for the 'grassroots level of church activity' and the theological grounding of this popular form of theologising was a conscious decision on the side of the leadership team. The question is, will it be possible to name it some kind of 'theology from under' and even a form of liberation theology, or do we find here something different motivated by other reasons or even another ecclesial epistemology? It is in other words a question about the hermeneutical choices, points of departure and theoretical underpinnings operative in their process of theologising. Do they see themselves as part of a bigger tradition or do they see themselves as belonging to the many independent traditions?

The second point is that it is quite obvious that the majority of participants in the network of the echurch originate from the Afrikaans-speaking community. Many of them have become disappointed in the church and stopped attending, even giving up their membership. Most of these people grew up in a theological background where a Reformed ecclesiology was the frame of understanding. One could ask: What is the underlying ecclesiology at work in the echurch and in what ways does it find expression in the different kinds of ministry of the movement? An important part of Reformed ecclesiology revolves around the ministry of Word and sacrament, and one wonders how the echurch facilitates this important aspect of ministry if one takes into account the different traditions, all of them with different interpretations of the role and function of these symbols of faith.

The third point is that it is quite obvious that what has been described as entrepreneurial leadership cannot be understood without referring to the dangers of a consumer culture and the role of materialism. The question is, how does the leadership of the echurch handle this challenge? Joubert himself is a seasoned academic and a New Testament scholar and therefore further conversations with him on this important topic could lead to interesting perspectives on the meaning of being church.

\section{Conclusion}

In the introduction of the article it was stated that one of the basic understandings of leadership relates to the fact that it is seen as the involvement of a person, group or organisation that influences and empowers enough people to follow and to bring about change in that area of life. The basic assumption in this understanding of leadership is that this kind of influence and empowerment takes place in real-life situations and with face-to-face contact between the leaders and the followers. The question that I wanted to investigate in the article was, taking into account these basic assumptions about leadership, whether one can speak of virtual leadership, where there is not necessarily face-to-face contact between the leaders and the followers.

In the evidence of the empirical data that I gathered through a personal interview with Joubert and also some literature and the website of the echurch, I want to conclude that it is indeed possible to speak of virtual leadership with certain specific characteristics. By making use of a theo-dramatic paradigm I discussed the stage and the role of technology and digital communication, the plot consisting of different forms of ministries, the audience and their participation as well as the challenge of community, and lastly the characters with special focus on the role of leadership. In the last section 
of the article the concept of 'entrepreneurial leadership' was developed as one way of understanding this form of leadership as part of 'online religion', in which one can see the development and encouragement to participate in different Christian activities summarised as spiritual growth, equipment of leadership and involvement in the need of the world.

\section{Acknowledgements Competing interests}

The author declares that he has no financial or personal relationships that may have inappropriately influenced him in writing this article.

\section{References}

Anderson, B., 1988, The unfolding drama of the Bible, 4th edn., Fortress Press, Minneapolis, MN

Baym, N.K., 2010, Personal connections in the digital age, Polity Press, Cambridge.

Brasher, B.E., 2004, Give me that online religion, Rutgers University Press, New Brunswick.

Brown, D., 2008, God and mystery in words: Experience through metaphor and drama, Oxford University Press, Oxford.

Campbell, H.A., 2013, 'Community', in H.A. Campbell (ed.), Digital religion: Understanding religious practice in new media worlds, pp. 3-67, Routledge, Abingdon.

Caulat, G., 2006, 'Virtual leadership', The Ashridge Journal 3, 6-11.

Childers, J. \& Smith, C.J. (eds.), 2008, Performance in preaching: Bringing the sermon to life, Baker Academic, Grand Rapids, MI.

Cloete, A., 2015, 'Living in a digital culture: The need for theological reflection', HTS Teologiese Studies/Theological Studies 71(2), Art. \#2073. http://dx.doi.org/ 10.4102/hts.v71i2.2073

Dawson, L.L., 2004, 'Religion and the quest for virtual community', in L.L. Dawson \& D.E. Cowan (eds.), Religion online: Finding faith on the Internet, pp. 75-89, Routledge, London.

De Wet, C.L., 2015, 'Entrepreneurial leadership training and theological education', in M. Naidoo (ed.), Contested issues in training ministers in South Africa, pp. 127-140, Sun Press, Stellenbosch.

Estes, D., 2009, SimChurch: Being church in the virtual world, Zondervan, Grand Rapids, MI.
Friesen, D.J., 2009, Thy Kingdom connected: What the church can learn from Facebook, the internet, and other networks, Emersion: Emergent Village resources for communities of faith series, Baker Books, Grand Rapids, MI.

Gaum, F., 2014, Die Kerkbode, 8 December.

Graham, E., 2009, 'Being, making and imagining: Towards a practical theology of technology', Culture and Religion: An Interdisciplinary Journal 10(2), 221-236. http://dx.doi.org/10.1080/14755610903077588

Healy, N., 2000, Church, world and the Christian life: Practical-prophetic ecclesiology, Cambridge University Press, Cambridge.

Hipps, S., 2009, Flickering pixels: How technology shapes your faith, Zondervan, Grand Rapids, MI.

Jinkins, M., 2012, 'Religious leadership', in B.J. Miller-McLemore (ed.), The WileyBlackwell Companion to Practical Theology, pp. 307-317, Ashgate, Aldershot.

Joubert, S., 2016, God is altyd tuis, viewed 26 February 2016, from http://www.ekerk. org/\#!God-is-altyd-tuis/ckfj/56d01dae0cf24bcda475f710

Joubert, S.J., 2010, 'Annus virualis: Enkele uitdagings wat die virtuele era van Web 2.0 aan relevante kerklike bedieninge stel', Nederduitse Gereformeerde Teologiese Tydskrif 51(3/4), 48-60.

Kerfoot, K.M., 2010, 'Listening to see: The key to virtual leadership', Nursing Economics 28(2), 114-119.

Leadbeater, C., 2009, We-think: Mass innovation, not mass production, 2nd edn., Profile, London. (Kindle version).

Miller, V., 2011, Understanding digital culture, Sage, Thousand Oaks, CA.

Osmer, R., 2005, The teaching ministry of congregations, Westminster, Louisville, KY.

Quash, B., 2005, Theology and the drama of history: Cambridge studies in Christian doctrine, Cambridge University Press, Cambridge.

Rice, J., 2009, The Church of Facebook: How the hyperconnected are redefining community, Routledge, London.

Siegel, L., 2008, Against the machine: Being human in the age of the electronic mob, Spiegel Sociology of Knowledge, Anchor, New York.

Thompson, G., 2006, 'Religious diversity, Christian doctrine and Karl Barth', International Journal of Systematic Theology 8(1), 3-24. http://dx.doi.org/ 10.1111/j.1468-2400.2006.00180.x

Van den Berg, J.A., 2012, 'Theoretical signposts for tracing spirituality within the fluid decision-making of a mobile virtual reality', HTS Teologiese Studies/Theological Studies 68(2), 1-6. http://dx.doi.org/10.4102/hts.v68i2.1290

Vanhoozer, K., 2005, The drama of doctrine: A canonical-linguistic approach to Christian theology, Westminster John Knox, Louisville, KY.

Van Saane, J.W., 2012, Geloofwaardig leiderschap, Uitgeverij Meinema, Zoetermeer.

Von Balthasar, H.U., 1988, Theo-drama: Theological dramatic theory, vol. 1: Prolegomena, Ignatius, San Francisco, CA.

Wilson, L. \& Moore, J., 2008, He wired church 2.0, Abingdon Press, Nashville, TN.

Wright, N.T., 1992, The New Testament and the people of God, Fortress Press, Minneapolis, MN.

Yukl, G.A., 2010, Leadership in organizations, Seventh global edition, Pearson, Upper Saddle River, NJ. 